\title{
NBSIR 75.747
}

\section{Building Energy Authority and Regulations Survey: State Activity}

Robert M. Eisenhard

Office of Building Standards and Codes Services

Center for Building Technology Institute for Applied Technology

National Bureau of Standards

Washington, D. C. 20234

June 1975

Preliminary Report

In cooperation with:

The Federal Energy Administration

Frank Zarb, Administrator

Roger W. Sant, Assistant Administrator

Energy Conservation and Environment

Building Research Development and

Demonstration Program 
. 


\section{BUILDING ENERGY AUTHORITY AND \\ REGULATIONS SURVEY: STATE ACTIVITY}

Robert M. Eisenhard

Office of Building Standards and Codes Services

Center for Building Technology

Institute for Applied Technology

National Bureau of Standards

Washington, D. C. 20234

June 1975

Preliminary Report

In cooperation with:

The Federal Energy Administration

Frank Zarb, Administrator

Roger W. Sant, Assistant Administrator

Energy Conservation and Environment

Building Research Development and

Demonstration Program

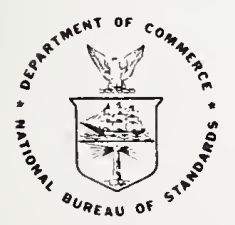

U.S. DEPARTMENT OF COMMERCE, Rogers C.B. Morton, Secretary

NATIONAL BUREAU OF STANDARDS, Ernest Ambler. Acting Director 
. 
Abstract . . . . . . . . . . . . . . . . . . . . . . 11

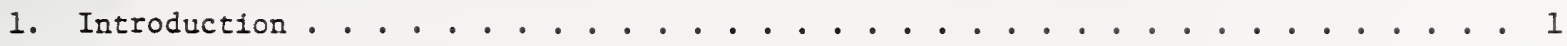

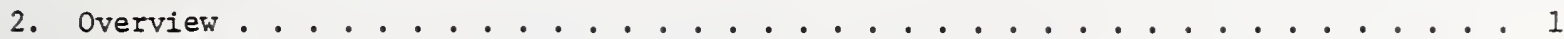

3. Acknowlegments . . . . . . . . . . . . . . . . . . . . . 2

4. Updating for Future Reports . . . . . . . . . . . . . . . . . . 2

Figure 1: State Authority to Regulate Building Energy Conservation . . . . . . . 3

Table 1: Summary of State Building Energy Authority and Regulatory Status . . . . . 4

5. Survey Results . . . . . . . . . . . . . . . . . . . . 5 


\section{Abstract}

Information describing the status of State regulations and authority to regulate energy use in new and existing buildings is presented in tabular form. The tables reference available information on pending bills, acts, or general authority which is embodied in a State Building Code Act. Programs relating to solar energy, insulation, and other building energy items are also listed.

Keywords: authority; building; energy; legislation; regulations; State. 
Robert M. Eisenhard

\section{Introduction}

The 1975 State legislative sessions evidence considerable activity and interest in providing for legislation that would insure energy conserving buildings. A voluntary consensus standard for building energy conservation titled "Energy Conservation in New Building Design" is under development by the American Society of Heating, Refrigerating, and Air-Conditioning Engineers, Inc. (ASHRAE). A great deal of interest has been shown in following the actions that States are taking in regulating energy use in new and existing buildings. The status of enabling legislation and technical regulations has been surveyed by telephone contacts with State building officials, energy officers, Governor's offices, and legislative reference services. The tables contained herein summarize the status of available information on building energy regulatory authority and regulations as of the period February 15 - April 15, 1975, during which this survey was taken. Because of rapid changes taking place in the building energy regulatory field at the State level, the actual status of some data presented in this report may be changed by the time of this publication.

\section{Overview}

Interest in State regulation of building energy utilization varies from State to State. Twenty-four States comprising those with sixty-five percent of the United States' population, report a high interest in building energy regulation; the remainder were about evenly split between moderate interest and 1ittle apparent interest. of those most interested, fourteen (Connecticut, Florida, Massachusetts, Michigan, Minnesota, Montana, New Mexico, North Carolina, Ohio, Oregon, Rhode Island, Virginia, Washington, and Wisconsin) had statewide building code authority and therefore a vehicle for energy regulations. Indiana also has a statewide code, but legislation adding energy conservation authority died in the Senate. Forty-one percent of the population of the country is located in States with authority to regulate energy use in buildings. Seven States (Alabama, Idaho, Iowa, Kansas, New Jersey, Pennsylvania, and Texas) have study groups or legislatures considering statewide building code laws. Ten States (Arizona, California, Colorado, Illinois, Nevada, New Hampshire, New York, Vermont, West Virginia, and Wyoming) have authority or were considering legislation dealing with building energy regulations separate from a statewide building code. Most States without statewide building codes find it difficult to envision effective State regulation in the building energy area. To them, establishment of an administrative organization to regulate this single facet of building design and construction seems difficult to justify.

As shown in figure 1, five States (California, North Carolina, Ohio, Oregon, and Wisconsin) have adopted building energy regulations. Colorado and Washington also have regulations of a limited nature. Colorado's regulations apply to multi-family dwellings in jurisdictions that do not have their own building code enforcement and Washington's regulations apply to buildings using electric heat. Three States (Connecticut, Michigan, and Minnesota) are in the process of developing regulations. Even though some States are adopting their own regulations (as required by legislation or administrative authority), most States appear to desire the anticipated ASHRAE Standard or a subsequent American National Standard as the basis for their regulations in the future. The remainder of the States with existing authority indicate that they plan to wait for a national consensus standard. Officials from several States without present statewide authority to regulate building energy use also express interest in the ASHRAE Standard as a basis for seeking authority or for recommending to local governments for their use.

A large number of solar energy and thermal insulation bills have been introduced in State legislatures. Most call for sales or property tax exemption or lower assessments for 
fossil fuel saving improvements. The data of introduction and comittees to which the bills have been assigned are noted in the following tables where known.

In the data presented, States are listed by alphabetical order with population rank noted in parentheses following the state name.

\section{Acknowledgments}

The author wishes to thank the State Delegate members of the National Conference of States on Building Codes and Standards, the State Energy Officers, and Legislative Reference Services personnel who provided information and documentation. A special thanks is extended to Michael J. Greene of the Council of State Governments Energy Project for the use of material from his listings of legislative activity.

\section{Updating for Future Reports}

It is planned that updating will be prepared in late 1975 when remaining legislative action will have been completed. Any new data or updating information as well as suggestions on format, content, or utility of this summary will be welcome and should be sent to:

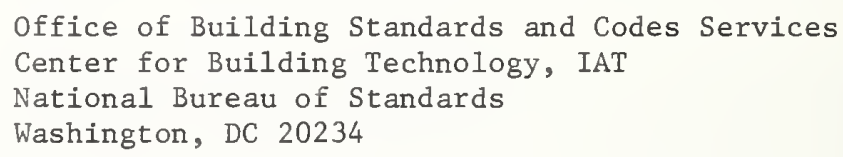




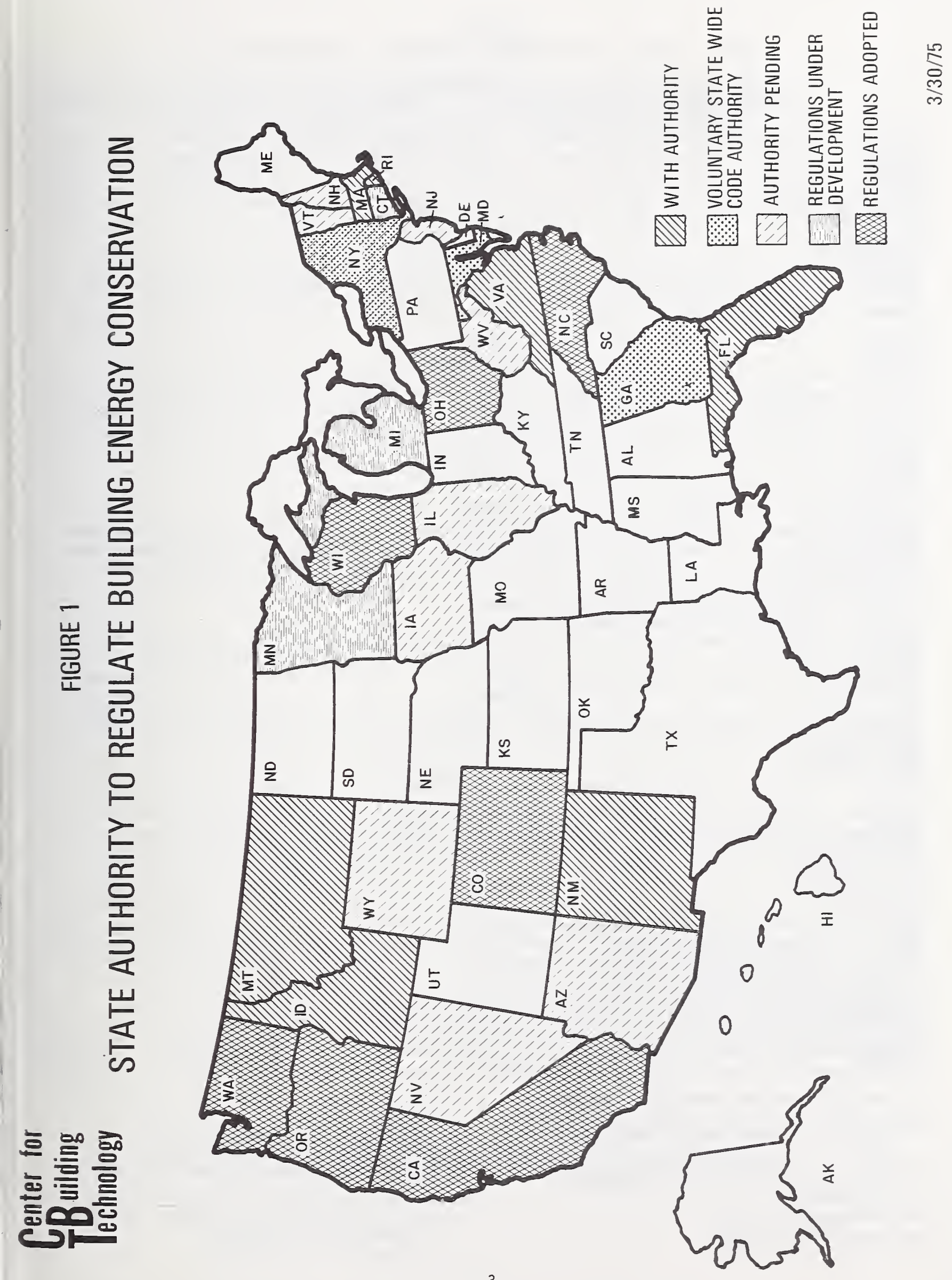


TABLE 1

Summary of State Building Energy Authority and Regulatory Status

\begin{tabular}{|c|c|c|c|c|c|c|}
\hline \multirow[b]{2}{*}{ State } & \multicolumn{2}{|c|}{ Building Energy Regulatory Authority } & \multicolumn{2}{|c|}{ Regulations } & \multicolumn{2}{|c|}{ Authority Being Considered } \\
\hline & $\begin{array}{c}\text { in Statewide } \\
\text { Code }\end{array}$ & $\begin{array}{c}\text { in Separate } \\
\text { Law }\end{array}$ & Promulgated & $\begin{array}{c}\text { Under } \\
\text { Development }\end{array}$ & $\begin{array}{c}\text { by } \\
\text { Legislature }\end{array}$ & $\begin{array}{l}\text { by Staff or } \\
\text { Study Group }\end{array}$ \\
\hline ALABAMA & & & & & & $\mathrm{x}$ \\
\hline ALASKA & & & & & & \\
\hline ARIZONA & & & & & $\mathrm{x}$ & \\
\hline ARKANSAS & & & & & & \\
\hline CALIFORNIA & & $\mathrm{X}$ & $x(f)$ & $\mathrm{X}(\mathrm{g})$ & & \\
\hline COLORADO & & & $x(k)$ & & $\mathrm{X}$ & \\
\hline CONNECTICUT & $\mathrm{X}$ & & & $\mathrm{X}$ & & \\
\hline DELAWARE & & & & & & \\
\hline FLORIDA & $\mathrm{x}$ & & & & & \\
\hline GEORGIA & $x(n)$ & & & & & \\
\hline HAWAII & & & & & & \\
\hline IDAHO & $\mathrm{x}$ & & & & & \\
\hline ILLINOIS & & & & & $\mathrm{X}$ & \\
\hline INDIANA & & & & & & \\
\hline IOWA & & & & & $\mathrm{X}$ & \\
\hline KANSAS & & & & & & $\mathrm{x}$ \\
\hline KENTUCKY & & & & & & \\
\hline LOUISIANA & & & & & & \\
\hline MAINE & & & & & & \\
\hline MARYLAND & $\mathrm{X}(\mathrm{n})$ & & & & & \\
\hline MASSACHUSETTS & $X(e)$ & & & & & \\
\hline MICHIGAN & $\mathrm{X}$ & & & $\bar{x}$ & & \\
\hline MINNESOTA & & $\mathrm{X}(\mathrm{d})$ & & $\mathrm{X}$ & & \\
\hline MISSISSIPPI & & & & & & \\
\hline MISSOURI & & & & & & \\
\hline MONTANA & $x(a)$ & & & & & \\
\hline NEBRASKA & & & & & & \\
\hline NEVADA & & & & & $\mathrm{X}$ & \\
\hline NEW HAMPSHIRE & & & & & $\mathrm{X}$ & \\
\hline NEW JERSEY & & & & & $\mathrm{x}$ & \\
\hline NEW MEXICO & $\mathrm{x}$ & & & & & \\
\hline NEW YORK & & $\mathrm{X}(\mathrm{b})$ & & & & $\mathrm{X}(\mathrm{c})$ \\
\hline NORTH CAROLINA & $\mathrm{X}$ & & $\mathrm{X}(\mathrm{h})$ & & & \\
\hline NORTH DAKOTA & & & & & & \\
\hline OHIO & $\mathrm{X}(\mathrm{i})$ & & $X(i)$ & & & \\
\hline OKLAHOMA & & & & & & \\
\hline OREGON & $\mathrm{x}$ & & $\mathrm{X}(\mathrm{h})$ & & & \\
\hline PENNSYLVANIA & & & & & & $\mathrm{X}$ \\
\hline RHODE ISLAND & $\mathrm{X}$ & & & & & \\
\hline SOUTH CAROLINA & & & & & & $\mathrm{X}$ \\
\hline SOUTH DAKOTA & & & & & & \\
\hline TENNESSEE & & & & & & \\
\hline TEXAS & & & & & & \\
\hline UTAH & & & & & & \\
\hline VERMONT & & & & & $\mathrm{X}$ & \\
\hline VIRGINIA & $\mathrm{x}$ & & & & & \\
\hline WASHINGTON & $\mathrm{x}$ & & $x(1)$ & & & \\
\hline WEST VIRGINIA & & & & & $\mathrm{X}$ & \\
\hline WISCONSIN & $\mathrm{x}$ & & $X(j)$ & & $X(m)$ & \\
\hline WYOMING & & & & & $\bar{x}$ & \\
\hline
\end{tabular}

(a) authority has been clarified by amendment

(b) authority to draft an energy conserving code

(c) authority to promulgate an energy conserving code

(d) authority in separate law but regulations become a part of the state building code

(e) as amended

(f) residential buildings

(g) commercial buildings (h) single family and multi-family residential,

3 stories and under

(i) excluding 1,2 , \& 3 family residential

(j) excluding 1 \& 2 family residential

(k) multi-family and manufactured buildings

(1) electric heat only

(m) pending legislation would extend building regulatory authority to 1 \& 2 family residential and manufactured buildings

(n) voluntary 


\section{Survey Results}

\section{$\operatorname{ALABAMA}(21) *$}

Legislative session begins in May. Administration proposes to

introduce, with the American Institute of Architects, a statewide building code bill; proposed in earlier legislative sessions but not passed.

\section{ALASKA (50)}

No reported proposed or existing legislation related to building energy.

SB 1321

Introduced $2 / 19 / 75$

Committees: Rules; Agriculture; Commerce and Labor

\section{ARIZONA (33)}

SB 1231 allows any taxpayer who acquires a solar energy device for the production of heat or electricity to amortize its cost over 60 months as a deduction in computing his net taxable income.

SB 1321 authorizes the adoption of standards and regulations for the use of thermal products and devices in new industrial, commercial, and residential construction. It also provides that costs of thermal improvements may be deducted from gross income and provides that such improvements not increase assessed evaluation of buildings for taxation purposes.

S 1011 relates to tax exemption for solar energy devices.
S 1011

Prefiled

\section{ARKANSAS (32)}

No reported proposed or existing legislation related to building energy.
SB 277

Passed in 1974

SB 144

Passed in 1974

\section{CALIFORNIA (1)}

Energy regulations for residential construction authorized by SB 277 (Title 25, Article 5, New Section 1094) were effective February 22, 1975. Some proposed changes are scheduled for hearing April 4, 1975. An Energy Design Manual for Residential Buildings is under development.

Energy regulations for nonresidential buildings authorized by SB 144 are under development.

* Number in parentheses indicates population ranking.

+ Bills that were reported to have become law are enclosed in a box. 
SB 510

Passed in 1974

SB 753

Passed in 1974

$\mathrm{AB} 1575$

Passed in 1974

SB 119

Prefiled

SB 214

Introduced $1 / 14 / 75$

AB 724

Introduced $2 / 6 / 75$

Committee: Housing and Community

Development

\section{S 218}

Introduced $1 / 14 / 75$

A 13

Introduced $1 / 14 / 75$

\section{S 215}

Introduced $1 / 9 / 75$

S 774

Introduced 2/11/75

Committee: Energy and Diminishing Materials

\section{S 428}

Introduced $2 / 17 / 75$

S 429

Introduced $2 / 17 / 75$
Energy regulations for mobile homes (SB 510) are authorized. SB 277, SB 144, and SB 510 are the responsibility of the Department of Housing; and Community Development.

Energy regulations for State building and school construction (SB 753) are to be implemented by the Office of the State Architect.

$\mathrm{AB} 1575$ establishes a State Energy Resources Conservation and Development Commission which will ultimately have power to regulate and adopt standards for residential and nonresidential construction.

Hearings were held March 19, 1975, on SB 119 which transfers authority to develop nonresidential building energy standards and regulations to the Department of Housing and Community Development. (This authority was transferred to the State Energy Resources Conservation and Development Commission as of January 1, 1975, by $A B$ 1575.)

SB 214 and companion $A B 724$ would require insulation of residential attic spaces to meet or exceed energy standards before a change in title can be recorded.

S 218 provides for a personal income tax deduction for solar energy devices.

A 13 exempts from property taxation all or any portion of property which is used as a solar energy system.

S 215 exempts from property taxation any equipment which is part of a solar energy system.

S 774 requires Energy Resources Conservation and Development Commission to submit recommendations for standards covering equipment utilizing solar energy for heating and cooling.

S 428 establishes authority to develop standards and designs for experimental housing utilizing solar energy for heating and cooling.

$\underline{\text { S } 429}$ relates to a solar energy demonstration project.

COLORADO (29)

Colorado has existing regulations covering energy which apply to multifamily dwellings ( 2 family and over), hotels, and motels in all jurisdictions without building code departments. 
HB 1002

Introduced $1 / 8 / 75$

Committees: Transportation and Energy; Appropriations

HB 1009

Introduced $1 / 9 / 75$

Committees: Transportation and Energy; Appropriations

HB 1010

Introduced $1 / 9 / 75$

Committees: Transportation and Energy; Finance
HB 1002 provides that the Senate Housing Board adopt thermal insulation regulations for residential buildings and provides for local adoption and enforcement of regulations no less stringent than State regulations.

HB 1009 provides that the State Industrial Commission adopt thermal insulation regulations for industrial and commercial structures and that local governments adopt and enforce no less stringent regulations.

HB 1010 provides a tax credit against property tax for a percentage of the cost of improvements to a residence when improvements reduce the amount of energy required to heat or cool such residence.

Both HB 1002 and HB 1009 have been passed by their reference comittee.

\section{CONNECTICUT (24)}

Connecticut has a statewide building code. Hearings were scheduled for March 7, 1975, on energy regulations but officials report that the State will consider a national consensus standard when available.

HB 7488

Committee: Regulated Activities

HB 7504

Committee: Environment

S 491

Introduced $1 / 29 / 75$

Committee: Regulated Activities

H 6146

Introduced $1 / 29 / 75$

Comittee: Finance

S 351

Introduced $1 / 29 / 75$

Committee: Regulated Activities

S 794

Committee: General Law

S 1096

Introduced $2 / 11 / 75$

Comittee: State and Urban Development
HB 7488 requires energy impact statements to be submitted to the building official for new conmercial or industrial buildings.

HB 7504 requires the State Building Code Standards Comittee to amend the State Building Code to incorporate energy conservation standards.

S 491 requires that life cycle cost analysis be provided for proposed state funded building projects and that these cost analyses be approved by the Commissioner of Public Works.

H 6146 provides that home insulation materials will be exempt from sales tax.

S 351 requires the State Building Code Standards Committee to report to the General Assembly on the inclusion of solar energy systems in the State Building Code; on standards for solar energy systems; and, the review of State and municipal buildings in regard to utilization of solar energy.

S 794 provides for the State to pay the building owner two hundred dollars for each dwelling unit equipped with a heat pump.

S 1096 requires the State Building Code Standards Committee to adopt stronger provisions for insulation of new homes and buildings. 
HB 5042

Introduced $1 / 10 / 75$

Committee: Environment

HB 6451

Introduced 2/4/75

Committee: Regulated Activities

HB 6444

Introduced $2 / 7 / 75$

Committee: Regulated Activities

\section{S 488}

Introduced $1 / 29 / 75$

Committee: Regulated Activities

S 412

Introduced $1 / 29 / 75$

Committee: Finance

\section{S 414}

Introduced $1 / 29 / 75$

Committee: Finance

S 348

Introduced $1 / 29 / 75$

Committee: Regulated Activities

S 441

Introduced $1 / 29 / 75$

Committee: Finance

\section{S 445}

Introduced $1 / 29 / 75$

Committee: Finance

H 7208

Introduced $2 / 5 / 75$

Committee: General Laws

H 5048

Introduced $1 / 8 / 75$

Committee: Environment

H 5236

Introduced $1 / 10 / 75$

Committee: Finance

\section{H 5873}

Introduced $1 / 27 / 75$

Committee: Regulated Activities
HB 5042 directs that the State Building Code Standards Committee investigate the feasibility of establishing standards for incorporating into the State Building Code to achieve climate control with minimum consumption of energy for new buildings and for alterations to existing buildings.

HB 6451 requires that no new mobile home may be sold in the State unless it meets minimum heat transmission standards.

HB 6444 requires that each building permit application for a new structure include a Certificate of Compliance by a registered architect or registered engineer that the design of the structure does not exceed the maximum energy consumption standards.

S 488 provides financial assistance to producers of solar energy devices.

S 412 provides for local property tax exemption for solar heating and solar electric generation equipment.

S 414 concerns sales tax exemption for solar heating and solar electric generation equipment.

S 348 provides for sales and property tax exemption for solar energy systems used in buildings.

S 441 concerns tax exemptions for solar energy devices.

S 445 eliminates sales tax on insulation material.

$\mathrm{H} 7208$ requires improvement of the quality and quantity of insulation used in buildings to conserve energy.

$\mathrm{H} 5048$ concerns deductions in property tax assessment for installation of solar energy systems.

H 5236 encourages installation of solar energy systems by allowing a deduction from assessed value equal to the increase in value due to the installation of such systems.

H 5873 concerns the making of solar energy and wind electrical generating devices tax exempt. 
H 7653

Introduced $2 / 6 / 75$

Committee: Regulated Activities

H 7666

Introduced $2 / 6 / 75$

S 1079

Introduced $2 / 7 / 75$

Committee: Regulated Activities
$\underline{H} 7563$ concerns solar energy as an innovative alternative for heating.

H 7666 allows an exemption in property tax assessment for buildings using solar energy systems.

S 1079 concerns development of alternative methods of energy production.

\section{DELAWARE (46)}

No reported proposed or existing legislation related to building energy.

\section{FLORIDA (9)}

The Florida Building Codes Act of 1974 includes energy conservation authority. Code and regulations must be prepared for the 1976 legislative session opening in April of 1976. Effective date of the building code will be January 1, 1977. ASHRAE 90P is being actively considered by an Energy Conservation Committee.

B 763

Prefiled
H 763 directs the Department of General Services to establish regulations for the implementation of energy conservation programs in public buildings.

\section{GEORGIA (15)}

Georgia has voluntary statewide code authority. No action has

been taken to adopt regulations related to building energy use.

SB 61

Introduced $1 / 21 / 75$

SB 62

Introduced $1 / 21 / 75$

\section{HAWAII $(40)$}

SB 61 allows a tax deduction with respect to the amortization of the amortizable basis of any certified new energy saving facility.

SB 62 proposes to exempt any new energy saving facility from gross proceeds and tangible personal property taxes.

\section{IDAHO (42)}

S 1013
S 1013 is a statewide building code bill approved March 27, 1975. Energy regulations, although not specifically mentioned in the law, could be promulgated under this act. 
HB 164

Introduced $1 / 14 / 75$

SB 602

Introduced $4 / 8 / 75$

Committees: Agriculture, Conservation \& Energy

\section{SB 1449}

Introduced 4/16/75

Committees: Public Welfare and Corrections

HB 2863

Introduced 4/12/75

Committee: Environment \& Energy

HB 1515 (companion to SB 602)

Introduced 4/9/75

Committee: Environment \& Energy
HP 164 provides for an exemption of up to $\$ 2,000$ from the valuation of real property for installation of solar heating or cooling systems.

SB 602 requires the Illinois Commerce Commission to establish minimum standards and specify procedures for enforcement concerning the insulation of all classes of new buildings to be heated or cooled. Also requires the Commission to explore, and if feasible, establish voluntary guidelines for all classes of existing buildings which are heated or cooled. SB 602 has been passed by Committee.

SB 1449 creates a State Building Code Council in the Department of Local Government Affairs and requires the Council to promulgate a State Building Construction Code.

HB 2863 creates in the Division of Energy, Department of Business and Economic Development, the authority to establish energy conservation requirements applicable to new construction throughout the State.

HB 1515 requires the Illinois Commerce Commission to adopt rules establishing minimum insulation standards for new buildings and requires compliance with these standards before the connection of natural gas or electric service. HB 1515 has been passed by Committee.

\section{INDIANA (11)}

Indiana has a statewide building code law but building energy authority is not specifically identified.

S 223 (Pub1ic Law 15)

Passed in 1974

HB 1140

Introduced $1 / 9 / 75$

Committee: Public Policy and

Veterans Affairs

\section{HB 1874}

Introduced 1/31/75

Comittee: Ways and Means
S 223 allows for an annual deduction from assessed valuation of real property the lesser of: (1) the difference between the assessed valuation with solar system and the assessed valuation without the system; or (2) two thousand dollars.

HB 1140 expands the authority of the Administrative Building Council, under the statewide building code law, to public buildings and would permit issuance of regulations regarding conservation of energy. Passed the House, but died in the Senate.

HB 1874 allows income tax deduction equal to the cost of insulation plus installation charges, to an individual who insulates his home. 
S 260

Introduced $1 / 15 / 75$

Committee: Finance
S 260 extends a tax deduction for property equipped with a solar heating or cooling system, to property equipped with a system powered by any non-fossil fuel.

IOWA (25)

SF 292

Introduced $3 / 10 / 75$
SF 292 is a statewide building code bill including energy conservation.

A bill has been proposed but not yet introduced to provide statewide mandatory building energy requirements, if the statewide code bill fails.

\section{KANSAS (28)}

Kansas officials hope to have an existing Building Code Study Committee extended past July 1, 1975.

Senate Concurrent Resolution No. 2 (SCR 2) Introduced $1 / 14 / 75$

Committee: Conservation and Natural Resources

H 2375

Introduced $2 / 17 / 75$
SCR 2 requests the Director of Architectural Services to study and report to the legislative coordinating council recommendations concerning standards for energy use and insulation of buildings within the State.

H 2375 provides ad valorem tax credits to homeowners whose homes meet minimum insulation standards.

\section{KENTUCKY (23)}

Kentucky does not have a legislative session in 1975 .

\section{LOUISIANA (20)}

Legislative session convenes in April 1975.

\section{MAINE (38)}

Bureau of Public Improvements has responsibility for State buildings, including schools, and is issuing a directive on Energy Conservation Measures.

S 56

Introduced $1 / 7 / 75$

(L.D. 125) Taxation
$\underline{S} 56$ exempts solar or wind power facilities from sales tax. 
HB 539

Passed in 1974

HB 1604

Signed 4/22/75

HB 506

Introduced $1 / 30 / 75$

Committee: Ways and Means

S 520

Introduced $2 / 13 / 75$

Committee: Budget and Taxation

HB 1007

Introduced $2 / 24 / 75$

Committee: Environmental Matters
HB 539 authorized the expansion of the Model Performance Building Code to include promotion of efficient utilization of energy resources. Maryland has established an ad hoc committee to review ASHRAE 90P.

HB 1604 provides that the property assessment for commercial and residential buildings that have conventional heating and cooling systems will not be raised if solar heating and cooling systems are added.

HB 506 encourages the use of solar energy systems, and excludes certain costs from taxes.

S 520 encourages use of solar energy by providing tax exemptions.

HB 1007 provides that all new structures deriving energy from fossil fuels must comply with ASHRAE 90P and be so certified by a registered professional engineer or a registered architect. The bill was unfavorably reported out of committee on $3 / 24 / 75$.

\section{MASSACHUSETTS (10)}

Massachusetts has building energy conservation authority in its statewide code law as amended. Recently the Energy Standards Committee recommended to the Governor, that if immediate action was necessary, ASHRAE 9OP (Jan. 14, 1975) should be adopted for State owned or financed buildings. The committee further recommended that ASHRAE 90P (Jan. 14, 1975) should be adopted for all buildings, effective Jan. 1, 1976.

H 3585

Introduced $1 / 2 / 75$

Committee: Taxation

H 3586

Introduced $2 / 2 / 75$

Committee: Taxation

\section{S 1366}

Prefiled

Committee: Taxation

S 1385

Prefiled

Committee: Taxation
H 3585 provides for an income tax exemption with respect to repairs and improvements of residences where the purpose is to reduce the consumption of energy. H 3585 died in the House.

H 3586 provided for a sales tax reimbursement with respect to repairs and improvements of residences where the purpose is to reduce the consumption of energy. H 3586 died in the House.

S 1366 provides exemption of property from taxation where solar energy is used.

S 1385 provides economic incentives for installation of solar and wind powered devices for climate control. 
Michigan has building energy conservation authority in its statewide code law and has started the development of regulations.

H 4137

Introduced $1 / 28 / 75$

Committee: Taxation

H 4138

Introduced $1 / 28 / 75$

Committee: Taxation

H 4597

Introduced $3 / 13 / 75$

Committee: Taxation
H 4137 provides that tangible property, used in new construction or for converting residential or commercial property from conventional systems for heating and cooling to a solar energy system, be exempt from sales tax.

H 4138 is similar to $\mathrm{H} 4137$ but applies to exemption from use tax.

H 4597 grants tax credits against State income tax for insulation and other energy conserving home improvements.

\section{MINNESOTA (19)}

The Building Code Division is authorized by Laws of 1974, Chapter 307 , to establish rules for the design, evaluation, construction or reconstruction of new buildings, and remodeling. The Division is seeking a 90 day extension of the April 1, 1975, promulgation date for energy conservation standards and rules. Final hearings are scheduled for May 6.

H 923

Introduced $3 / 13 / 75$

Committee: Environment

S 1042

Introduced $3 / 20 / 75$

Committee: Government Operations

H 85

Introduced $1 / 20 / 75$

S 281

Introduced $2 / 6 / 75$

Committee: Taxes and Tax Laws
$\mathrm{H} 923$ and the companion bill S 1042 provide an extension for the promulgation of building energy design standards to August 1, 1975.

H 85 provides for the deduction from property assessment of the value of a solar heating or cooling system, or the assessment with the addition of the system minus the assessment without the system, whichever is less.

S 281 provides a property tax deduction for solar energy heating or cooling systems.

\section{MISSISSIPPI (30)}

No reported proposed or existing legislation related to building energy.

\section{MISSOURI (13)}

No reported proposed or existing legislation related to building energy. 
Montana has a statewide building code law and is reported to be waiting for a national consensus standard.

HB 473

Introduced $2 / 17 / 75$

Committee: Natural Resources
$\underline{H B} 473$ requiring adoption of rules in the State Building Code to promote efficient use of energy, was passed and signed by the Governor $3 / 24 / 75$.

NEBRASKA (35)

No reported proposed or existing legislation related to building energy.

\section{NEVADA (47)}

The Public Works Board has energy design criteria for State buildings. These criteria were effective for all designs started April 1, 1974.

A 716

Introduced $4 / 23 / 75$

Committee: Commerce
A 716 requires adoption of minimum insulation standards for all public and private buildings.

\section{NEW HAMPSHIRE (41)}

HB 479

Committee: Ways and Means

SB 269

Introduced $4 / 23 / 75$

Committee: Energy and Consumer Affairs
HB 479 allows towns and cities to adopt by local referendum property tax exemptions for persons owning realty equipped with solar heating or cooling systems.

SB 269 establishes standards for maximum consumption of depletable energy in new buildings. It requires certification by an architect or professional engineer that the building meets the standards.
A 1299

A 1274

Introduced $3 / 18 / 74$

Committee: Taxation

\section{A 1275}

Carried over

Committee: Taxation
A 1299, New Jersey's State Uniform Construction Code Act, has passed the Assembly and is being considered by the Senate. Prior to passage it was amended to specifically reference energy conservation. Senate passage is expected. Officials report plans to use a national consensus standard.

A 1274 exempts sales of all materials used in conservation of heat within a building from the Sales and Use Tax Act.

A 1275 exempts energy conservation improvements, certified by the tax assessor as such, from real property taxation. 


\section{NEW MEXICO (37)}

New Mexico has building energy authority under a Statewide Building Code and the Senate has previously passed Memorial 非 requesting the Construction Industries Commission to review and revise the Uniform Building Code to establish construction methods to promote conservation of energy resources. New Mexico officials are waiting for a national consensus standard.

S 19

Introduced $1 / 21 / 75$

S 106

Introduced $1 / 27 / 75$
S 19 requires a certificate from the Mechanical Board that new construction meets energy construction standards.

S 106 provides for a gross receipts tax deduction for energy-saving materials.

\section{NEW YORK (2)}

New York has authority to prepare an energy efficient construction code for all new buildings (SB 9451, AB 11519, Chapter 824, 1974 Laws).

Also drafted and sent to the Governor is an act to allow the State Building Code Council to promulgate an energy code.

The Public Service Commission has issued energy regulations covering all buildings using new gas service.

S 239

Prefiled

A 2512

Introduced $2 / 4 / 75$

S 2882

Introduced $2 / 18 / 75$

Comittee: Local Government

\section{A 3342}

Introduced $2 / 12 / 75$

Committee: Environment

\section{A 659}

Prefiled

Committee: Local Governments

\section{S 896}

Prefiled

Committee: Finance
S 239 and the companion bill A 2512 exempts from sales and use tax, insulation, weatherstripping, storm windows and doors, and caulking compound.

S 2882 grants partial exemption from assessment of real property to owner who uses solar energy for cooling or heating said real property.

A 3342 establishes program for development of prototype, solar powered heating system for residential and commercial building structures.

A 659 permits owner of property equipped with solar energy heating or cooling system to have deducted annually from assessed valuation thereof the lesser of (1) the assessed value with the solar system minus the value of the system or (2) the value of the system.

S 896 requires that the Office of General Services develop standards for solar energy systems. 
North Carolina has a Statewide Building Code. Energy regulations for all one and two family dwellings and all new multiple family dwellings, three stories in height or less, were adopted

September 10, 1974, effective January 1, 1975. Officials report plans to use a national consensus standard.

HB 1520

\section{HB 1527}

Introduced $1 / 28 / 75$

Committee: Industry, Business, and Labor

\section{NORTH DAKOTA (45)}

HB 1520 provided for an excise tax on coal consumed in the State to provide funds for solar energy research. The bill was indefinitely postponed in the House.

HB 1527 authorized the State-owned Bank of North Dakota to provide low interest loans for persons who convert their existing housing or construct new housing with heating systems utilizing solar, waste products, or electricwind systems. The bill passed the House, was amended in the Senate to allow the Bank to guarantee loans and eliminated the low interest provision. The bjll failed in the Senate.

SB 2439

Introduced $1 / 28 / 75$

Signed 4/8/75

Committee: Finance and Taxation
Senate Concurrent

Resolution No. 4042
SB 2439 provided that systems utilizing solar energy for heating or cooling of buildings would be exempt from property tax in the State and also exempt from sales and use tax of the State. The bill was approved by the Senate, but prior to approval the House deleted the sales and use tax exemption. Effective date is July 1, 1975.

SCR 4042 calls for a Legislative Council Study of alternate energy sources. This has been passed by the Senate and passage by the House is expected.

\section{OHIO (6)}

Ohio has a Statewide Building Code which covers all buildings except one, two, and three family dwellings. Regulations have been promulgated as Chapter BB 48, an amendment to the 1970 Edition of the "Ohio Building Code." These regulations with the exception of BB 48-02.01 will be effective June 1, 1976. BB 48-02.01 which was effective March 1, 1975, provides for interim energy data collection and analysis.

H 626

Introduced $3 / 27 / 75$
H 626 establishes a revolving fund to make loans for home improvements for energy conservation purposes.

\section{OKLAHOMA (27)}

No reported proposed or existing legislation related to building energy. 
Oregon has statewide building code authority. Regulations for residential construction three stories or less were effective July 1, 1974. Officials will consider a national consensus standard when available.

HB 2036

Introduced $1 / 17 / 75$

Committee: Environment, Agriculture, and Natural Resources
SB 230

HB 2037

SB 483

SB 209

Introduced $1 / 23 / 75$

HB 2201

Introduced $1 / 24 / 75$

HB 2200

Introduced $1 / 23 / 75$

HB 2202

Introduced $1 / 23 / 75$

HB 2203

Introduced $1 / 23 / 75$

HB 2204

Introduced $1 / 23 / 75$

H 2046

Introduced $1 / 17 / 75$

Committee: Environment, Agriculture, and Natural Resources
HB 2036 amends the comprehensive planning laws to allow county planning commissions to recommend ordinances governing height and set-back of buildings, the utilization of incident solar energy and includes public incentives for overall energy conservation.

SB 230 establishes standards for maximum consumption of certain types of energy for new non-industrial structures. Prior to issuance of a permit the bill requires that a certificate of compliance be issued by an architect or registered professional engineer stating that such structure has been designed so as not to exceed maximum standards.

HB 2037 allows a State personal income tax deduction, not to exceed $\$ 500$, for thermal insulation of not more than one existing residence.

SB 483 creates Department of Energy. It provides a wide role for the Department, including promotion of efficient use of energy.

SB 209 provides tax exemption on increased value of property as a result of solar heating or cooling.

HB 2201 allows eligible veterans to obtain a loan from the Oregon War Veteran's Fund for the purpose of installing solar energy collection, storage, and delivery systems to a home.

HB 2200 calls for solar heating and cooling demonstrations at the University of Oregon.

HB 2202 provides a tax exemption on increased value of property as a result of solar energy heating and cooling systems.

HB 2203 provides a tax credit for costs involved in installation of solar heating and cooling systems.

HB 2204 authorizes the Housing Division to make loans for solar heating and cooling of buildings.

H 2046 exempts from personal income tax the first $\$ 500$ expended for a solar energy system for a single residence. 
Pennsylvania has a House subcommittee considering legislation for a statewide building code, including energy conservation.

HB 421

Introduced $2 / 11 / 75$

Committee: Finance

HB 262

Introduced $2 / 5 / 75$

Committee: Finance

HB 239

Introduced $2 / 4 / 75$

Committee: Finance
HB 421 provides for sales tax exemption for equipment used to construct or convert certain buildings for the use of solar energy systems for heating and cooling.

HB 262 excludes the material and installation costs for solar energy systems for heating and cooling from sales and use taxes.

HB 239 exempts storm windows and doors and insulation materials for use in residences from retail sales tax.

\section{RHODE ISLAND (39)}

Rhode Island has a Statewide Building Code Law with the building code to be effective August 1, 1975. Officials report plans to use a national consensus standard when available.

S 286

Introduced $2 / 18 / 75$

Committee: Special Legislation
S 286 requests the Rhode Island Building Code Standards Committee to include in the proposed statewide building code, standards requiring new buildings to be constructed and insulated so as to conserve energy.

\section{SOUTH CAROLINA (26)}

South Carolina officials are considering an act to allow a statewide building code with energy conservation.

H 2774

Introduced $4 / 8 / 75$

Committee: Ways and Means
H 2774 creates a committee to study revision of building codes to achieve conservation of energy.

\section{SOUTH DAKOTA (44)}

SB 283

Introduced $2 / 18 / 75$

Signed $3 / 26 / 75$

\section{H 569}

Introduced $1 / 28 / 75$

Committee: Taxation
SB 283 allows a property assessment deduction for the utilization of solar energy systems. Effective date is July 1, 1975.

$\underline{H} 569$ provides property tax deduction for the utilization of solar energy systems.

\section{TENNESSEE (18)}

No reported proposed or existing legislation related to building energy. 
Texas has no existing building energy authority. Dean Raymond D. Reed of Texas A \& M University and Chairman of a Task Force on Building Code for Texas has prepared a report for the Governor's Energy Advisory Council recommending the adopting of a State building code including conservation of energy in buildings.

H 429

Introduced $2 / 3 / 75$

Committee: Revenue and Taxation

H 1158

Introduced $3 / 3 / 75$

Committee: Natural Resources

S 516

Introduced $3 / 3 / 75$

Committee: Natural Resources
H 429 relates to tax exemptions and deductions for solar energy devices.

H 1158 and the companion bill S 516 requires the State Building Commission to write an energy conserving building code for all state buildings including University buildings. The code is to be made available to Texas cities as a model.

\section{UTAH (36)}

SB 117

Introduced $1 / 20 / 75$

SB 209

Introduced $2 / 7 / 75$
SB 117 provides for the adoption of code provisions dealing with energy conservation in the design, construction, and use of State buildings. It also provides for studies of energy use in buildings and encourages voluntary adoption of the code provisions developed for State buildings, by political subdivisions and industry.

SB 209 provides authority in the State building Board to initiate and supervise an energy conservation project designed to construct dwelling units utilizing a minimum of fuel.
H 69

Introduced $1 / 8 / 75$

S 29

S 88

Introduced $2 / 7 / 75$

H 206

Introduced $1 / 23 / 75$

Committee: Taxation
H 69 provides for the appointment of energy conservation officers, the adoption of regulations governing the insulation of buildings, and prohibiting the sale of gas, electricity, coal, or oil to owners of buildings which do not comply.

S 29 provides that a town may exempt from taxation real and personal property used for the production, but not the sale, of energy.

S 88 provides for State standards for solar energy systems which are manufactured or sold in the State.

H 206 permits municipalities to exempt from real estate and personal property taxes, equipment and facilities used in the production of alternate sources of energy. 
House Document No. 7 notes that the State Board of Housing which promulgates the Statewide Building Code, is relying on anticipated national building energy standards.

HB 1381

Introduced $1 / 17 / 75$

Committee: Genera1 Laws

HB 1465

Introduced $1 / 20 / 75$

Committee: General Laws

HB 1811

Introduced $1 / 21 / 75$

Committee: General Laws

HB 1808

HJR 268

Introduced $1 / 21 / 75$

Committee: Conservation and Natural

Resources

HB 1820

Introduced $1 / 21 / 75$

Committee: Finance
HB 1381 proposed to add to the State Building Code certain insulation standards. HB 1381 did not pass the General Assembly.

HB 1465 proposed to add to the State Building Code requirements for storm doors and windows. HB 1465 did not pass.

HB 1811 provided that the State Building Code shall include requirements that all single family dwelling plumbing would be constructed to facilitate future installation of solar water heating equipment. HB 1811 did not pass.

HB 1808 allowed deductions from gross income, for tax purposes, the cost of thermal design improvements; including improvements of insulation, solar collectors, and storm windows and doors. The bill included upper costs limits. HB 1808 did not pass.

HJR 268 called for the examination of the feasibility of using solar energy for heating and cooling of State facilities.

HB 1820 provides tax savings relating to income tax and amortization of solar energy systems. HB 1820 did not pass.

\section{WASHINGTON (22)}

Washington has a statewide building code law and also has electric heating regulations.

HB 664

Introduced $2 / 19 / 75$

Committee: Transportation and Utilities
SB 2106

Introduced $1 / 16 / 75$

Committee: Transportation and Utilities

SB 2375

Introduced $2 / 3 / 75$

Committee: Transportation and Utilities

All three (3) bills above are scheduled for hearing March 21, 1975.
HB 664 establishes minimum thermal insulation standards for all three-story or less frame buildings for human occupancy, which are heated or mechanically cooled. A substitute for HB 664 has been offered which establishes thermal insulation and design standards for residential occupancy as an addition to present statewide codes.

SB 2106 requires the analysis of energy consumption and life cycle cost of all major publicly owned or leased facilities.

SB 2375 exempts residential solar heating equipment and installation from sales and use taxes. 
H 1344

Introduced $2 / 20 / 75$

H 1138

Introduced $2 / 6 / 75$

Committee: Finance
H 1344 authorizes the establishment of energy standards for the purposes of minimizing fuel consumption for heating in new residential, commercial, and public buildings. H 1344 was not reported out of committee.

H 1138 exempts solar heating and cooling systems from taxation.

\section{WISCONSIN (16)}

Wisconsin has a State Building Code covering all buildings except one and two family dwellings. Rules pertaining to building energy conservation were adopted November 18, 1974 , and were effective January $1,1975$.

\section{A 268}

Introduced $2 / 5 / 75$

Committee: Tax Exempt

SB 105

Introduced $1 / 30 / 75$

Committee: Governmental and Veteran Affairs

SB 106

Introduced $1 / 30 / 75$

Committee: Governmental and Veteran Affairs
A 268 provides tax exemption for solar heat or light sources.

SB 105 calls for creation of a one and two family dwelling code and include energy conservation regulations.

SB 106 calls for creation of a manufactured building code including energy conservation.

\section{WYOMING (49)}

H 54

Prefiled
H 54 creates a Council within the Department of Environmental Quality. It requires electric utilities to submit energy forecasts to the Council and imposes a tax on generation of électricity to fund council activities. The Council is directed to regulate the lighting and insulation of new buildings and prescribe operating efficiency standards for appliances, etc. 
NBS-114A (REV. 7-73)

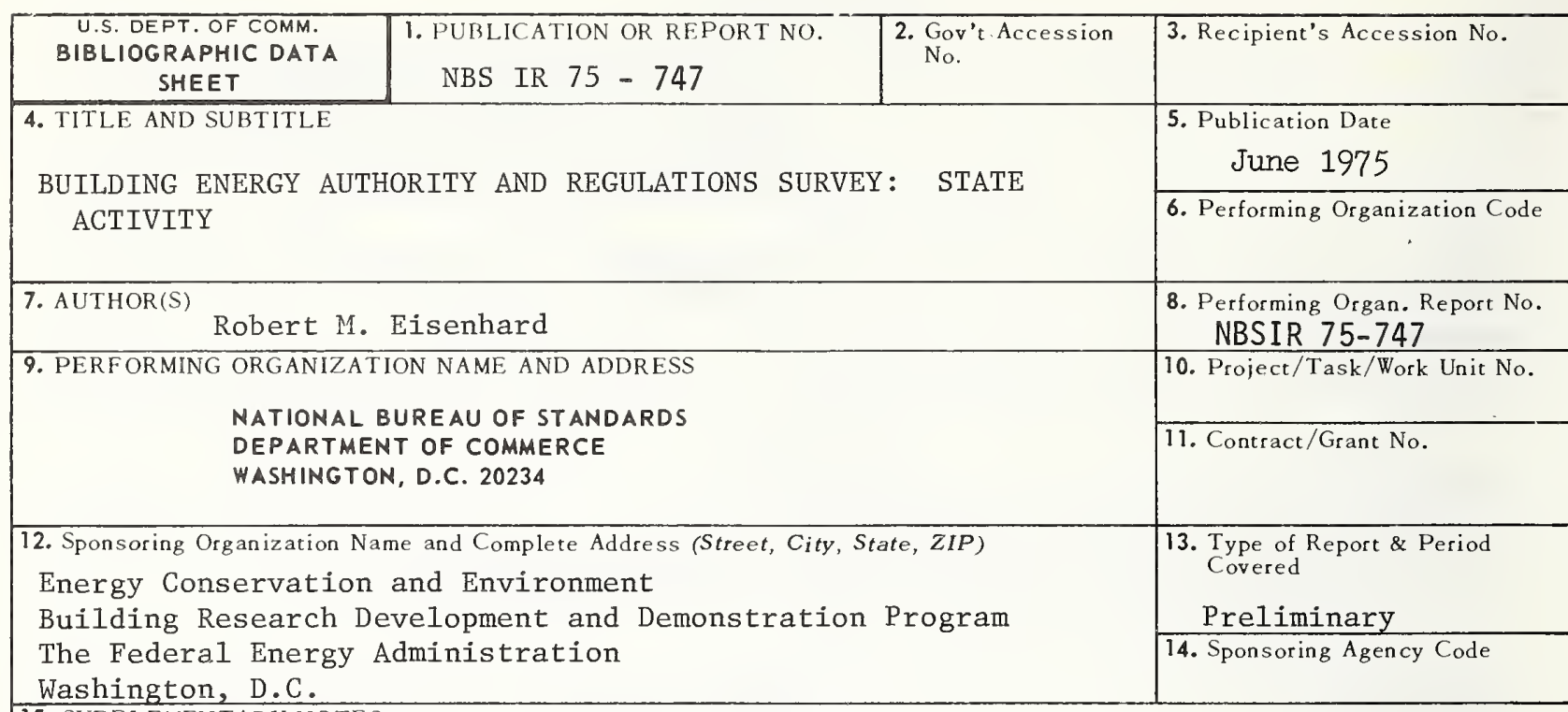

15. SUPPLEMENTARY NOTES

16. ABSTRACT (A 200-word or less factual summary of most significant information. If document includes a significant bibliography or literature survey, mention it here.)

Information describing the status of State regulations and authority to regulate energy use in new and existing buildings is presented in tabular form. The tables reference available information on pending bills, acts, or general authority which is embodied in a State Building Code Act. Programs relating to solar energy, insulation, and other building energy items are also listed.

17. KEY WORDS (six to twelve entries; alphabetical order; capitalize only the first letter of the first key word unless a proper name; separated by semicolons)

Authority; building; energy; legislation; regulations; state

18. AVAILABILITY

Unlimited

$\square$ For Official Distribution. Do Not Release to NTIS

Order From Sup. of Doc., U.S. Government Printing Office Washington, D.C. 20402, SD Cat. No. C13

Q Order From National Technical Information Service (NTIS) Springfield, Virginia 22151

\begin{tabular}{|l|c|}
\hline $\begin{array}{l}\text { 19. SECURITY CLASS } \\
\text { (THIS REPURT) }\end{array}$ & 21. NO. OF PAGES \\
UNCL ASSIFIED & 25 \\
\hline $\begin{array}{l}\text { 20. SECURITY CLASS } \\
\text { (THIS PAGE) }\end{array}$ & 22. Price \\
UNCLASSIFIED & USCOMM-DC 29042-P74
\end{tabular}





\section{.}

